\title{
Pengalaman ibu hamil primigravida dengan riwayat menikah usia dini
}

\author{
Nur Purnama ${ }^{1^{*}}$, Immawanti Immawanti ${ }^{2}$, Masniati Masniati ${ }^{3}$, Lina Fitriani ${ }^{4}$ \\ ${ }^{1,3}$ Fakultas IImu Kesehatan, Universitas Sulawesi Barat, Indonesia \\ ${ }^{2}$ Stikes Marendeng Majene, Indonesia \\ ${ }^{4}$ Stikes Bina Generasi Polewali Mandar, Indonesia \\ *Coresponding Author: nurpurnama24@gmail.com
}

\begin{abstract}
Abstrak
Pendahuluan: Kehamilan usia dini merupakan kehamilan yang terjadi pada remaja putri berusia kurang dari 20 tahun. Tujuan penelitian ini untuk mengetahui pengalaman ibu hamil primigravida dengan riwayat menikah usia muda di wilayah kerja Puskesmas Kecamatan Wonomulyo. Metode: Desain penelitian fenomenologi, partisipan yaitu ibu hamil primigravida dengan riwayat menikah usia muda di wilayah kerja Puskesmas Kecamatan Wonomulyo, pengumpulan data dengan teknik wawancara mendalam kemudian data dianalisa dengan menggunakan model Miles and Huberman. Hasil: Pengalaman ibu primigravida dengan riwayat menikah usia dini di wilayah kerja Puskesmas Kecamatan Wonomulyo mengalami perubahan dalam berbagai aspek yaitu perubahan fisik, psikologis, sosial, budaya, dan spiritual. Simpulan: Perubahan yang terjadi pada primigravida dipengaruhi oleh peran dan dukungan dari suami, keluarga, dan tenaga kesehatan. Partisipan dalam penelitian ini juga memiliki persepsi positif dan negatif dalam masa kehamilannya. Diharapkan instansi terkait dapat memberikan perhatian lebih terhadap permasalahan selama kehamilan primigravida khususnya bagi ibu hamil usia muda.
\end{abstract}

Kata kunci: Kehamilan; menikah usia dini; primigravida

\section{The experience of primigravida pregnant women with a history of early marriage in the Wonomulyo Health Center work area}

\begin{abstract}
Introduction: Pregnancy at an early age of pregnancy in young girls aged less than 20 years. The aim of the study was to see the experiences of primigravida pregnant women with a history of early marriage in the working area of the Wonomulyo District Health Center. Methods: Phenomenological research design, participants were primigravida pregnant women with a history of early marriage in the working area of the Wonomulyo District Health Center, studied the data using interview techniques then the data were analyzed using the Miles and Huberman model. Results: The experience of primigravida mothers with a history of early marriage in the working area of the Wonomulyo District Health Center experienced changes in various aspects, namely physical, psychological, social, cultural, and spiritual changes. Conclusions: Changes that occur in primigravida, the role and support of husbands, families, health workers. Participants in this study also had positive and negative perceptions during their pregnancy. It is hoped that related agencies can pay more attention to primigravida pregnancy, especially for young pregnant women.
\end{abstract}

Keywords: Pregnancy; early marriage; primigravida

How to Cite: Purnama, N., Immawanti, I., Masniati, M., \& Fitriani, L. (2019). Pengalaman ibu hamil primigravida dengan riwayat menikah usia dini. NURSCOPE: Jurnal Penelitian dan Pemikiran Ilmiah Keperawatan, 5(2), 8-16

\section{PENDAHULUAN}

Badan Kependudukan dan Keluarga Berencana Nasional (BKKBN) menyebutkan usia pernikahan yang ideal yaitu 21 tahun untuk perempuan dan 25 tahun untuk laki-laki. Usia tersebut dianggap masa yang paling baik untuk berumah tangga, karena sudah matang secara biologis dan psikologis. Berdasarkan data dari UNICEF, Indonesia tercatat sebagai salah satu dari 10 negara di dunia atau tepatnya di urutan ketujuh di dunia dan urutan kedua di ASEAN dengan angka perkawinan anak tertinggi. UNICEF mengestimasi setiap tahun 12 juta perempuan memutuskan menikah dini di seluruh dunia. Merujuk 
kepada Badan Sasaran Pembangunan Berkelanjutan PBB, UNICEF menargetkan dunia bebas praktik pernikahan di bawah umur pada 2030 mendatang. Prevalensi perkawinan usia anak lebih banyak terjadi di pedesaan dengan angka 27,11\%, dibandingkan di perkotaan berada pada angka 17,09\%. Data Badan Pusat Statistik (BPS) tahun 2015 provinsi dengan prevalensi perkawinan usia anak tertinggi adalah Sulawesi Barat dengan prevalensi 34,22 \%. Sebanyak 11,58 \% anak pada usia di bawah 16 tahun dan $10 \%$ remaja usia 15-19 tahun sudah pernah melahirkan atau sedang hamil anak pertama (SDKI, 2012).

Kehamilan usia dini merupakan kehamilan yang terjadi pada remaja putri berusia kurang dari 20 tahun. Kehamilan tersebut dapat disebabkan karena hubungan seksual (hubungan intim) dengan pacar, dengan suami, pemerkosaan, maupun faktor-faktor lain yang menyebabkan sperma membuahi telurnya dalam rahim perempuan tersebut (Masland, 2004). Menurut Tobing (2007) kehamilan di umur kurang dari 20 tahun bisa menimbulkan masalah, karena kondisi fisik belum $100 \%$ siap. Untuk umur yang dianggap paling aman menjalani kehamilan dan persalinan adalah 20-35 tahun. Di rentang usia ini kondisi fisik wanita dalam keadaan prima. Sedangkan setelah umur 35 tahun, sebagian wanita digolongkan pada kehamilan beresiko tinggi terhadap kelainan bawaan dan adanya penyulit pada waktu persalinan. Di kurun umur ini, angka kematian ibu melahirkan dan bayi meningkat, sehingga akan meningkatkan kecemasan (Astria, 2009).

Menurut WHO, sekitar 830 wanita meninggal setiap hari karena sebab yang dapat dicegah terkait dengan kehamilan dan persalinan. Komplikasi selama kehamilan dan persalinan merupakan penyebab utama kematian dan kecacatan. Komplikasi menyebabkan hampir $75 \%$ dari semua kematian ibu adalah perdarahan hebat, infeksi, tekanan darah tinggi selama kehamilan, aborsi yang tidak aman, dan penyakit selama kehamilan. Untuk menghindari kematian ibu, penting juga untuk mencegah kehamilan yang tidak diinginkan dan terlalu dini (WHO, 2018).

Salah satu target Sustainable Development Goals (SDGs) periode 2016-2030 adalah pada tahun 2030 mengurangi rasio kematian ibu melahirkan global menjadi kurang dari 70 per 100.000 kelahiran hidup. Jumlah kasus kematian ibu di Provinsi Sulawesi Barat tahun 2017 yaitu sebanyak 39 dan Kabupaten Polewali Mandar menjadi Kabupaten dengan angka terbesar jumlah kasus kematian ibu yaitu sebanyak 11 orang (Profil Kesehatan Provinsi Sulawesi Barat, 2017). Primigravida adalah keadaan dimana seorang wanita mengalami masa kehamilan untuk pertama kalinya (Manuaba, 2007). Bagi ibu primigravida kehamilan merupakan pengalaman pertama kali di periode kehidupannya. Situasi tersebut dapat menyebabkan perubahan fisik maupun psikologis ibu (Bethsaida \& Pieter, 2013).

Hasil komunikasi interpersonal pada seorang ibu hamil primigravida usia remaja dengan riwayat menikah usia muda di Desa Campurjo wilayah kerja Puskesmas Kecamatan Wonomulyo menunjukkan bahwa kehamilan pertama kalinya membuat dia merasa cemas, dimana selama kehamilan mengalami perubahan pada fisik yaitu perubahan bentuk tubuh yang ditandai dengan pembesaran perut dan peningkatan berat badan. Ibu tersebut mengatakan keluhan selama kehamilan yaitu merasa pusing, penglihatan gelap, sering buang air kecil, dan kadang terbangun tengah malam. Peran suami yaitu membantu selama masa kehamilan. Dalam kepercayaannya pantang makanan selama kehamilan yaitu udang, kepiting dan cumi. Tradisi yang dilakukan yaitu upacara adat tujuh bulan (Komunikasi interpersonal, 2019).

Berdasarkan studi pendahuluan yang telah dilakukan, jumlah ibu hamil primigravida usia remaja di wilayah kerja Puskesmas Kecamatan Wonomulyo tahun 2018 sebanyak 60 orang. Berdasarkan wawancara dengan bidan di puskesmas Wonomulyo menjelaskan bahwa dari kejadian kehamilan pada usia muda dengan status pernikahan yang resmi umumnya keluhan utamanya sama dengan ibu hamil lainnya yaitu mual, muntah, dan pusing. Namun pada kehamilan wanita remaja yang hamil di luar nikah sulit diketahui keluhan apa saja yang terjadi karena mereka baru akan memeriksakan diri 
ketika usia kandungannya sudah besar. Aspek psikologis, wanita remaja yang hamil ada rasa takut dan khawatir karena belum berpengalaman. Wanita hamil remaja juga berisiko karena organ tubuhnya belum sempurna sehingga bisa menyebabkan sulit dalam persalinan.

Berdasarkan uraian di atas, peneliti tertarik meneliti tentang Pengalaman Kehamilan Perempuan Primigravida dengan Riwayat Menikah Usia Muda. Tujuan penelitian ini adalah mengetahui pengalaman ibu hamil primigravida dengan riwayat menikah usia muda di wilayah kerja Puskesmas Wonomulyo.

\section{METODE}

Jenis penelitian ini menggunakan metode deskriptif kualitatif dengan desain penelitian fenomenologi. Fokus model pendekatan fenomenologi adalah pengalaman tersebut berkaitan dengan fenomena tertentu yang sangat berarti bagi individu yang bersangkutan, pengalaman yang dibahas bukan sekedar pengalaman biasa, melainkan pengalaman yang berkaitan dengan struktur dan tingkat kesadaran individu secara langsung maupun tidak langsung. Karena model pendekatan fenomenologi memfokuskan pada pengalaman pribadi individu, sehingga subjek penelitiannya yaitu orang yang mengalami langsung fenomena atau kejadian yang terjadi, bukan individu yang mengetahui secara tidak langsung atau melalui media tertentu pada fenomena yang terjadi (Ghony \& Fauzan 2012).

Partisipan dalam penelitian ini adalah ibu hamil primigravida dengan riwayat menikah usia muda. Metode pengambilan sampel menggunakan teknik purposive sampling dengan kriteria inklusi: (1) ibu hamil primigravida (2) Usia kurang dari 20 tahun (3) Komunikatif dan kooperatif (4) Bersedia menjadi partisipan. Tidak ada kriteria baku mengenai besarnya jumlah partisipan pada penelitian kualitatif. Jumlah partisipan dapat banyak atau sedikit, tergantung pada apa yang ingin diketahui oleh peneliti, serta tersedianya sumber daya dan waktu. Sampel dianggap telah memadai apabila telah mencapai saturated level (tingkat kejenuhan). Disebut jenuh yaitu bila informan berikutnya telah memberikan informasi yang sama dengan informan sebelumnya atau tidak ada informasi baru yang diperoleh (Jahja, 2017).

Instrumen yang digunakan dalam penelitian ini yaitu panduan wawancara (interview guide), buku catatan, dan alat rekam. Peneliti melakukan pengumpulan data dengan teknik wawancara mendalam (in-depth interviewing) selama 45 sampai 60 menit untuk setiap partisipan atau sesuai kesepakatan. Teknik analisa data yang digunakan peneliti menggunakan model Miles and Huberman. Dalam penelitian kualitatif, analisa data dilakukan pada saat pengumpulan data berlangsung dan setelah selesai pengumpulan data selama periode tertentu (Miles and Huberman, 1984 dalam Sugiyono, 2007). Proses analisa data dalam penelitian ini yaitu reduksi data (data reduction), penyajian data (data display), penarikan kesimpulan atau verifikasi data (conclusions drowing/verifiying)

Empat prinsip utama dalam etik penelitian keperawatan yang diperhatikan dalam penelitian ini yaitu menghormati harkat dan martabat, menghormati privasi dan kerahasiaan subjek, menghormati keadilan dan inklusivitas, serta memperhitungkan manfaat dan kerugian yang ditimbulkan. Keabsahan data dilakukan untuk membuktikan apakah penelitian yang dilakukan merupakan penelitian ilmiah sekaligus menguji data yang diperoleh. Uji keabsahan data meliputi uji credibility, transferability, dependability, dan confirmability (Sugiyono, 2010).

\section{HASIL DAN PEMBAHASAN}

Partisipan dalam penelitian ini berjumlah tujuh orang dan berdomisili di wilayah kerja puskesmas Wonomulyo. Setelah dilakukan analisa data, penelitian ini menghasilkan tujuh tema. Tema-tema tersebut yaitu (1) perubahan fisik selama kehamilan, (2) perubahan psikologi selama kehamilan, (3) perubahan sosial selama kehamilan, (4) perubahan budaya selama kehamilan, (5) perubahan spiritual 
selama kehamilan, (6) peran suami, keluarga dan tenaga kesehatan selama kehamilan, (7) persepsi ibu tentang kehamilan.

Tabel 1. Karakteristik partisipan

\begin{tabular}{ccccccc}
\hline No & Usia & Pkerjaan & Agama & Suku & Pendidikan & Usia \\
\hline P1 & 19 & IRT & Islam & Mandar & SMP & 9 bulan \\
\hline P2 & 19 & IRT & Islam & Mandar & SMA & 9 bulan \\
\hline P3 & 19 & IRT & Islam & Bugis & SD & 4 bulan \\
\hline P4 & 15 & IRT & Islam & Jawa & SD & 5 bulan \\
\hline P5 & 15 & IRT & Islam & Jawa & SD & 8 bulan \\
\hline P6 & 19 & IRT & Islam & Mandar & SMA & 3 bulan \\
\hline P7 & 17 & IRT & Islam & Jawa & SMP & 4 bulan \\
\hline
\end{tabular}

Tema 1 merupakan perubahan fisik yang dialami partisipan selama kehamilan yaitu peningkatan berat badan, penurunan berat badan, tekanan darah rendah, kram perut dan nyeri perut bagian bawah, peningkatan nafsu makan, pembesaran ukuran perut, sering sendawa dan buang angin, sesak, tumbuh jerawat, wajah kusam, rambut kusam, kuku tumbuh lebih cepat, hidung membengkak, gusi berdarah, nyeri bagian tubuh belakang, bengkak dan kram pada kaki serta sering buang air kecil. Perubahan yang paling banyak dialami partisipan yaitu mual muntah dan kurang nafsu makan, pusing dan sakit kepala, serta payudara membesar. Seperti pada salah satu pernyataan berikut:

"mual-mual ka' muntah juga, pusing juga, jarang makan" (P2).

Hal ini sesuai dengan penelitian oleh Afiyanti (2004) tentang pengalaman wanita dalam menjalani masa-masa kehamilan pertama menunjukkan bahwa semua partisipan mengalami berbagai ketidaknyamanan fisik, diantaranya mengalami mual muntah dan peningkatan frekuensi berkemih.

Tema 2 merupakan perubahan psikologis yang dialami partisipan selama kehamilan yaitu merasa gerakan anak, merasa tidak sehat, merasa takut bayi lahir tidak tepat waktu, merasa takut sakit saat melahirkan, merasa takut bayi lahir tidak normal, merasa bahagia, dan merasa cemas. Seperti pada salah satu pernyataan berikut:

“biasanya tuh kaya' ada rasa cemas, cemas kaya' bagaimana nanti, fikirkan kalau melahirkan nanti bagaimana" (P4).

Hal ini sejalan dengan penelitian yang dilakukan oleh Gitayanti dkk (2016) bahwa masalah psikologis yang terjadi pada perempuan primigravida dengan riwayat menikah usia dini selama kehamilan yaitu kecemasan. Primigravida memiliki tingkat kecemasan yang lebih tinggi dalam menghadapi persalinan dibandingkan dengan multigravida. (Eka dan Fahriani, 2014). Usia merupakan salah satu faktor yang mempengaruhi kecemasan pada seseorang, dimana semakin tua usia seseorang maka semakin baik pula tingkat kematangan emosinya (Sandock, 2014).

Adapun perubahan perilaku yang dialami partisipan yaitu gampang emosi, gampang menangis, gampang lelah, kesulitan tidur, dan sebagian besar partisipan mengalami ngidam. Seperti pada salah satu pernyataan berikut:

"ngidam juga dari awal sampe sekarang tapi agak mendingan sih. Ngidamnya yang manis-manis, kadang pengen minum es buah, biasa juga pernah mau makan pedes padahal ndak boleh katanya" (P7)

Tema 3 yaitu perubahan sosial selama kehamilan menunjukkan bahwa seluruh partisipan mengatakan hubungan dengan keluarga selama kehamilan tetap baik, hubungan dengan tenaga kesehatan khususnya bidan baik, dan 2 orang partisipan mengatakan mengalami peningkatan hubungan dengan wanita hamil lainnya selama kehamilan. Seperti pada salah satu pernyataan berikut: 
“biasa sering cerita pengalaman sama keluarga yang hamil misalnya kaya' waktu pas bulan pertama itu kamu merasakan bagaimana? Sering ngidam pokoknya mintanya yang aneh-aneh begitu, biasa juga kakinya bengkak-bengkak juga dia bilang, trus ada juga kantong matanya, trus kulitnya juga sama kaya' berubah semua. Ada juga yang sudah melahirkan keluarga juga kan dikasi saran-saran harus rajin-rajin olahraga sama banyak-banyak berdoa juga" (P7).

Pada penelitian yang dilakukan oleh Rina dkk (2014) tentang interaksi sosial ibu hamil juga menunjukkan bahwa mayoritas ibu hamil memiliki interaksi sosial dengan suami dan tetangga $(100 \%)$, sementara itu interaksi dengan orang tua $(27,77 \%)$ dengan mertua $(12,96 \%)$ dengan bidan $(11,11 \%)$ dengan sesama ibu hamil $(9,25 \%)$.

Dukungan sosial terutama dukungan keluarga memegang peranan penting pada perilaku ibu primigravida dalam menjaga kehamilan. Ibu hamil terutama ibu primigravida membutuhkan dukungan fisik dan psikologis yang harus dipenuhi. Ibu hamil pun membutuhkan pengobatan, istirahat, dan akan merasa bahagia mendapat pertolongan praktis. Dukungan yang diberikan oleh keluarga (sebagai sumber terdekat yang dimiliki responden) akan menimbulkan respon ibu hamil bahwa mereka merasa diterima, merasa dihargai, merasa diperhatikan, mendapatkan rasa aman dan mendapatkan kemudahan menyelesaikan kesulitan, sehingga dapat menghadapi kehamilan dengan lancar (Adiatiawarman dkk, 2008).

Tema 4 yaitu perubahan budaya selama kehamilan menunjukkan bahwa lima dari tujuh partisipan masih memiliki kepercayaan tentang pantangan makanan selama kehamilan, makanan tersebut yaitu udang, kepiting, ikan gabus, ikan betok, mangga kweni, makanan yang mentah atau makanan yang dibakar langsung, dan terbanyak yaitu pantang makan nanas dan juga cumi. Seperti pada salah satu pernyataan berikut:

"tidak boleh makan udang, cumi, iwak kocolan, kepiting" (P5).

Hal ini sejalan dengan penelitian yang dilakukan oleh Cahyanto \& Wulansari (2018) tentang aspek gizi dan makna simbolis tabu makanan ibu hamil di Indonesia yang menunjukkan bahwa makanan yang paling banyak ditabukan adalah kelompok lauk pauk hewani. Jika dilihat dari aspek gizi, lauk pauk hewani sangat dianjurkan untuk ibu hamil (Kemenkes, 2014).

Enam dari tujuh partisipan memiliki kepercayaan tentang pantangan perilaku selama kehamilan, antara lain pantang mandi saat petang, masuk lalu keluar lewat pintu yang berbeda, buang sampah lewat jendela, baring telentang, makan di piring kecil, makan sambil baring, menyapu tidak langsung dibuang, dan pantang duduk di depan pintu. Seperti salah satu pernyataan berikut:

"tidak boleh singgah di pintu" (P2)

Hal ini sesuai dengan penelitian Rina (2014) yang menunjukkan ibu hamil meyakini larangan duduk di depan pintu karena dapat mempersulit persalinan. Sedangkan penelitian Mochtar (2010) mengungkapkan bahwa mudah atau sulitnya persalinan ditentukan dari segi power, passage, passanger, psikis dan penolong serta keterampilan dalam proses persalinan bukan karena duduk di depan pintu bisa mempersulit persalinan.

Empat dari tujuh partisipan meyakini anjuran perawatan kehamilan tradisional yaitu 2 orang di urut (pijat), 1 orang dianjurkan minum telur ayam dan madu jika sudah dekat waktu persalinan, dan 1 orang dianjurkan minum jamu jika sudah melahirkan. Seperti pada salah satu pernyataan berikut:

"diurut dukun, biasa kan jatuh kebawah janinnya" (P5)

Adapun enam dari tujuh partisipan menyakini untuk melaksanakan upacara adat ketika usia kehamilan tujuh bulan (syukuran tujuh bulanan kehamilan), seperti pada pernyataan berikut: 
"iye acara 7 bulanan saja" (P1)

Tema 5 yaitu perubahan spiritual selama kehamilan menunjukkan bahwa 3 dari tujuh partisipan mengatakan ibadah sholat terganggu, seperti pada salah satu pernyataan berikut:

"iye susah berdiri (sholat) kan sudah membesar (perut)" (P1). Gerakan-gerakan shalat bagi wanita hamil dapat menjadi sarana relaksasi dan memberikan banyak manfaat bagi kesehatan tubuh (Khalid, 2013).

Seluruh partisipan mengatakan ibadah puasa terganggu, seperti pada salah satu pernyataan berikut: "jarang puasa, karena muntah" (P3). Menurut ustazah Aini Aryani, ibu hamil dan menyusui memang boleh tidak berpuasa. Tapi, jika dia tidak ada kekhawatiran terhadap dirinya dan anak yang dikandungnya atau disusuinya, maka dia tetap wajib berpuasa.

Empat dari tujuh partisipan mengamalkan doa-doa selama kehamilan, seperti pada salah satu pernyataan berikut:

"iya minta doa supaya anaknya soleh soleha, selamat melahirkan, bayinya sehat sempurna" (P7).

Menurut Purnama (2017), melalui berdoa, ritual dan keyakinan agama dapat membantu seseorang dalam koping pada saat mengalami stress kehidupan, karena adanya pengharapan dan kenyamanan. Agama mempunyai peran penting dalam mengelola stress, agama dapat memberikan individu pengarahan atau bimbingan, dukungan, dan harapan, seperti halnya pada dukungan emosi (Rammohan dan Subbakrishna, 2002).

Tema 6 yaitu peran suami, keluarga, dan tenaga kesehatan selama kehamilan menunjukkan bahwa peran suami atau keluarga yaitu memberikan dukungan emosional, membantu pekerjaan rumah tangga, mendengarkan keluhan, menemani periksa kesehatan, dan seluruh partispan mengatakan suami atau keluarga memperhatikan kebutuhan makan minum dan istirahat serta memberi nasehat. Seperti pada salah satu pernyataan partisipan berikut:

"Biasa suami, orang tua, semua. Selalu ji juga na kasi nasehat. Kalau kerja ka' bilang jangan terlalu karna nanti kecapean" (P3)

Adapun peran tenaga kesehatan yaitu memberikan pendidikan kesehatan dan melakukan kunjungan rumah, seluruh partisipan mengatakan tenaga kesehatan berperan memberikan pelayanan KIA dan memotivasi. Seperti pada salah satu pernyataan partisipan berikut:

"Ditimbang berat badan, tekanan darah, tamblet tambah darah, tes lab di puskesmas juga kemaren" (P5)

Hal ini sesuai dengan penelitian oleh Afiyanti (2004) tentang pengalaman wanita dalam menjalani masa-masa kehamilan pertama menunjukkan bahwa para partisipan memerlukan berbagai bantuan dan dukungan baik berupa pengetahuan untuk mengatasi berbagai ketidaknyamanan fisik dan psikologis yang dapat dialami selama masa hamil atau bantuan nyata untuk mengurangi beban berat sehari-hari dari pekerjaan mereka. Seorang wanita membutuhkan bantuan dan dukungan ketika dirinya hamil untuk pertama kali, karena belum memiliki pengalaman dan pengetahuan sebelumnya dalam mengatasi ketidaknyamanan fisik dan keluhan-keluhan yang mereka alami.

Tema 7 yaitu persepsi ibu selama kehamilan menunjukkan bahwa persepsi partisipan terhadap kehamilan dibagi menjadi persepsi positif dan persepsi negatif. Persepsi positif yang diungkapkan oleh tiga orang partisipan yaitu bahagia, tidak khawatir, dan butuh perjuangan. Seperti pada salah satu pernyataan partisipan berikut:

“pertama pas ka' kutau kalo hamil ka' kaya' bagaimana di', bahagia sekali ka' kurasa” (P2). 
Kegembiraan pada kehamilan pertama akan mengembangkan rasa kepuasan dan kebanggaan, karena mampu menjalankan tugas dan kewajibannya sebagai wanita pencetak generasi penerus (Setyaningrum, 2013). Selain persepsi positif ada pula persepsi negatif yang diungkapkan oleh tiga orang partisipan yaitu takut merasa sakit dan berfikir ternyata kehamilan itu banyak keluhan. Seperti pada salah satu pernyataan partispan berikut:

“kalo menurut saya kan baru pertama kali hamil ya ternyata orang hamil itu kaya' sering mual muntah trus mau makan ini itu, kadang mau semua dimakan tapi kadang keluar semua, trus badan gampang sekali lelah padahal baru kerja berapa doang sudah capek, baru gampang emosi lah kaya' nangis kah atau ngambek, ya trus pokoknya banyak yang terjadi kaya' perut membesar kan jadi harus hati-hati bawanya" (P7).

Perasaan ini wajar dihadapi sebagian primigravida dalam masa kehamilan. Menghadapi masa persalinan merupakan suatu kondisi konkrit yang mengancam diri ibu hamil yang menyebabkan perasaan tegang, khawatir dan takut (Zanden, 2007). Menurut Bobak dkk (2005), pada umumnya seorang ibu yang pertama kali hamil akan senang dengan kehamilannya, tapi disaat yang sama tumbuh pula kecemasan. Penyebab perubahan emosi ini disebabkan oleh perubahan hormonal yang terjadi pada ibu hamil. Perubahan emosi ini sangat mengganggu bagi ibu hamil (Farrer, 2001).

\section{SIMPULAN DAN SARAN}

Hasil penelitian menunjukkan bahwa pengalaman ibu hamil primigravida dengan riwayat menikah usia dini di wilayah kerja Puskesmas Kecamatan Wonomulyo mengalami perubahan dalam berbagai aspek diantaranya perubahan fisik, psikologis, sosial, budaya, dan spiritual. Suami, keluarga, dan tenaga kesehatan turut berperan serta memberikan berbagai dukungan dalam masa kehamilan dan partisipan dalam penelitian ini memiliki persepsi positif dan persepsi negatif.

\section{DAFTAR PUSTAKA}

Aditiawarman. (2008). Manfaat Dukungan Sosial Keluarga Pada Perilaku Antisipasi Tanda Bahaya Kehamilan Pada Ibu Primigravida. Fakultas Keperawatan Universitas Airlangga Surabaya.

Afiyanti, Y. (2004). Studi Fenomenologi Tentang Pengalaman Wanita di Daerah Pedesaan Dalam Menjalani Masa Kehamilan Pertama. Jurnal Keperawatan Indonesia.

Aini, A. (2019). Ketentuan Berpuasa bagi ibu hamil dan menyusui dalam islam. Hai Bunda.com. Diperoleh dari https://www.haibunda.com

Bappenas. (2017). Rencana Pemerintah Jangka Menengah Nasional 2015-2019. Diperoleh dari https://www.bappenas.go.id

Bethsaida, J., \& Pieter, HZ. (2013). Pendidikan Psikologi untuk Bidan. Yogyakarta: Rapha Publishing.

BKKBN. (2017). Usia Pernikahan Ideal 21-25 Tahun. Diperoleh dari https://www.bkkbn.go.id

BPS. (2017). Perkawinan Usia Anak di Indonesia 2013 dan 2015. Jakarta: Badan Pusat Statistik.

BPS. (2018). Provinsi Sulawesi Barat Dalam Angka 2018. Sulbar: Badan Pusat Statistik Provinsi Sulawesi Barat.

Cahyanto \& Wulansari. (2018). Aspek Gizi Dan Makna Simbolis Tabu Makanan Ibu Hamil di Indonesia. Jurnal Ekologi Kesehatan, 17(1). 
Dinas Kesehatan Provinsi Sulawesi Barat. (2017). Profil Kesehatan Provinsi Sulawesi Barat 2017. Diperoleh dari https://www.depkes.go.id

Eka, R., \& Fahriani, S. (2014). Perbedaan Tingkat Kecemasan Dalam Menghadapi Persalinan Antara Primigravida dan Multigravida. Departemen Epidemiologi Fakultas Kesehatan Universitas Airlangga Surabaya, JawaTimur, Indonesia.

Farrer, H. (2001). Perawatan Maternitas edisi 2. Jakarta: EGC.

Gitayanti R, Sulistyorini L, \& Hardiani RS (2016). Pengalaman Kehamilan Perempuan Primigravida dengan Riwayat Menikah Usia Dini di Desa Balet baru Kecamatan Sukowono. e-Jurnal Pustaka Kesehatan, 4 (1).

Hidayat, A. (2017). Penjelasan Teknik Purposive Sampling Lengkap Detail. Diperoleh dari https://www.statistikian.com

Jahja, A. (2017). Subyek Responden Informan dan Partisipan. Diperoleh dari https://dosen.perbanas.id

Kementrian Kesehatan Republik Indonesia. (2014). Pedoman Gizi Seimbang. PGS. Jakarta: Kementerian Kesehatan Republik Indonesia.

Kementrian Kesehatan Republik Indonesia. (2018). Hasil Utama Riskesdas 2018. Jakarta: Kementrian Kesehatan RI.

Khalid, FA. (2013). Ajaibnya Gerakan Shalat Bagi Perkembangan Janin. Diva Press.

Masland, R.P \& Estridge, D. (2004). Apa yang Ingin Diketahui Remaja Tentang Seks Alih Bahasa: Windy, M.T. Jakarta: Bumi Aksara.

Mochtar, R. (2010). Sinopsis Obstetri Fisiologi Patologi, Jilid 1. Jakarta: EGC.

Naurah, S. (2017). Faktor-Faktor Penyebab Maraknya Kasus Pernikahan Dini. Diperoleh dari https://sitinauranh16.blogspot.com

Rahmad, P. (2017). Penyelesaian Stress melalui Coping Spiritual. UIN Raden Intan Lampung; Lampung.

Rammohan \& Subbakrishna (2002). Religious Coping and Psychological Well-being in Carers of Relatives With Schizophrenia.

Rina, Tria, Lusiana (2014). Sosial, Budaya serta Pengetahuan Ibu Hamil yang Tidak Mendukung Kehamilan Sehat. Jurusan Kebidanan Poltekkes Kemenkes; Medan.

Sandock BJ (2014). Buku Ajar Psikiatri Klinis. Edisi 2. Jakarta: EGC.

Setyaningrum, RF. (2013). Hubungan usia ibu primigravida dengan tingkat kecemasan ibu hamil dalam menghadapi persalinan di Wilayah Kerja Puskesmas Pembantu Kandangan Bawen.

Sugiyono. (2010). Metode Penelitian Pendidikan Pendekatan Kuantitatif, kualitatif. Bandung: Alfabeta.

The Global Goals For Sustainable Development. (2019). Diperoleh dari www.globalgoals.org 
World Health Organization. (2018). Coming of Age: Adolescent Health. Diperoleh dari http://www.who.int

Zanden JWV., Crandell TL., Crandell CH. (2007). Human Development (8thed). USA:McGraw-Hill Companies,Inc. 